Copyright (C) 2019 by Academic Publishing House Researcher

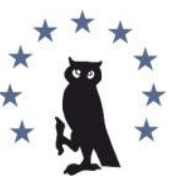

Published in the Russian Federation

European Researcher. Series A

Has been issued since 2010.

E-ISSN 2224-0136

2019, 10(2): 86-93

DOI: 10.13187/er.2019.2.86

www.erjournal.ru

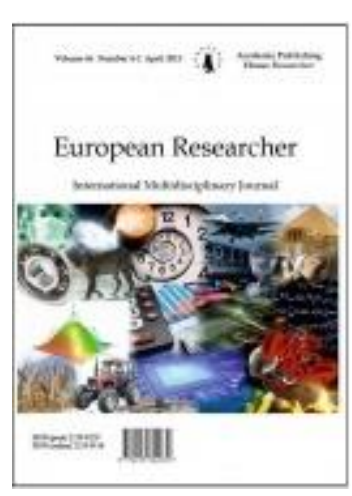

\title{
The Right to Freely Conduct Business in the Legal System of Vietnam Nowadays
}

\author{
Hue Duong Dang a, *, Luan Nguyen Thanh a, Ngoc Ha Thi b, Tung Nguyen Xuan ${ }^{c}$ \\ ${ }^{a}$ Hanoi Law University, Socialist Republic of Vietnam \\ ${ }^{\mathrm{b}}$ Southwest State University, Russian Federation \\ c Bac Ninh Province, Socialist Republic of Vietnam
}

\begin{abstract}
This study focuses on clarifying and bringing about a systematic view of the right to freely conduct business in the current legal system of Vietnam by analyzing the regulations on freedom of enterprise which have already been prescribed in The Constitution 2013, the specialized laws including Law on Enterprise 2014, Law on Investment 2014 and the Civil Code 2015. Especially, this study thoroughly goes into analyzing and clarifying the particularly important role of the provisions in the Civil Code 2015 with the recognition and assurance of the implementation of the right to freely conduct business in Vietnam nowadays.

Keywords: the right to freely conduct business, the Constitution, Law on enterprise, Law on investment, Civil code, Vietnam.

\section{Introduction}

Since the execution of "Doi Moi" (12/1986) which introduced reforms intended to facilitate the transition from a centrally planned economy into building and developing the "Socialistoriented market economy", the right to freely conduct business has finally been recognized as a certain requirement of the market economy and as a basic right of citizen in Vietnam. From that time until now, the law and code which constitute the legal system of Vietnam have been constantly revised and supplemented to further improve the right to freely conduct business, in order to meet the new requirements of the economy and promote the economic development of the country. With the introduction of the Constitution 2013, the Law on Enterprise 2014, the Law on Investment 2014 and the Civil Code 2015, the right to freely conduct business continues to be more and more improved with many new breakthrough regulations. All of these contents will be presented in detail in this study.
\end{abstract}

\section{Document and study method}

2.1. This research is executed on the currently provisions of Vietnamese law about the right to freely conduct business, and some of published researches as follows: "The new points in Law on Enterprise 2014, which create advantageous condition for enterprise" (Luan Nguyen Thanh, 2015); "The amendments and supplements of the Law on real estate business 2014 about the

\footnotetext{
${ }^{*}$ Corresponding author

E-mail addresses: duongdanghue1955@gmail.com (H. Duong Dang), thanhluanbdbp@gmail.com (L.Thanh Nguyen), ngoccivillaw@gmail.com (N. Ha Thi), mrtung310@gmail.com (T. Nguyen Xuan)
} 
business of real estate service" (Tuyen Nguyen Quang, Luan Nguyen Thanh, 2016); The Legal Nature of Land Use Rights in Vietnam" (Luan Thanh Nguyen, Ngoc Thi Ha, 2018).

2.2. It's completed by simultaneously using different research techniques such as analysis, general, dialectical materialism, interpretation and comparison.

\section{Discussion}

First of all, it must be affirmed that: Freedom in business is a constitutional right of organizations and individuals in Vietnam, which is recognized in the Constitution 1992 and extended in the Constitution 2013.

Vietnam now has five Constitutions: 1946, 1959, 1980,1992 and 2013. However, not every Constitution fully recognizes the basic rights of citizens, including the right to freely conduct business. This is explainable because the content of the constitution in general and the content of the basic rights of citizens in particular can not be determined in the Constitution arbitrarily. However, it must come from socio-economic circumstances of the country in each historical period. Only since 1986 when Vietnam started the construction of a socialist-oriented market economy, the principle of business freedom as a requirement of a market economy and the right to freely conduct business as a fundamental right of citizens have been recognized in the constitution (Article 57 of the Constitution 1992 and Article 33 of the Constitution 2013).

The right to freely conduct business is not only recognized in the Vietnamese Constitution but also in the Constitution of many countries around the world. Why has the right to freely conduct business always been recognized in such a solem way by the Constitution of the countries? The answer is simple. Without this principle, the market economy can not be established and developed. Thanks to the recognition of the right to freely conduct business in the Constitution, every individual and legal person has motivation and strong legal basis to promote his dynamism and creativity, so that he can feel secure to invest the human resources and property into production and business activities, making more and more asset and material for society. The reality shows that one of the basic reasons for the failure of a centrally planned economy in Vietnam as well as in all socialist countries was that the State was not aware of the importance of the right to freely conduct business, therefore, it did not acknowledge the right in the Constitution and consequently resulted in the abolition of all creative capacities, the desire to enrich legally of people, failure in encouraging all organizations and individuals to invest in production and business, waste of financial resources and material resources in society.

In the process of building a socialist-oriented market economy in Vietnam, the right to freely conduct business was also recognized by the Constitution in a different way. This is not only shown in terms of form, but also in terms of content. Specifically, if Article 57 of the Constitution 1992 only states: "Citizens have the right to freely conduct business in accordance with the law", then the Constitution 2013 has shown this right in a different way, more tightly and fully: "Everyone has the right to freely conduct business in industries which are not prohibited by law" (Article 33). The advancement in content of the Constitution 2013 in recognizing the right to freely conduct business is expressed as firstly to expand the subject component of this right through the replacement of the term "citizen" in the term "everyone". "Everyone" means any person who, in legal science, the concept of "person" is understood in a much broader sense than the ordinary meaning. In the legal sense, "person" includes not only human in flesh and skin (also known as natural person, personal) but also the legal person (legal entity). "People" here also include not only Vietnamese citizens, but also foreign nationals and non-citizens, as long as they live, work, study legally in Vietnam. In addition, the new in provision of Article 33 of the Constitution 2013 compared to Article 57 of the Constitution 1992 is that the new Constitution has more clearly and strictly defined the right to freely conduct business through making the limitation of this right under which people have the right to do all things that are not prohibited by law. Obviously, the Constitution as a basic law of Vietnam only provides such principled provision, and what is banned and many other specific issues related to ensuring the exercise of rights to freely conduct business freedom will be regulated under the Constitution (Law, Ordinance, Decree). 


\section{Next, it is necessary to affirm the role of the documents under the Constitution in ensuring the exercise of the right to freely conduct business \\ - The role of the Law on Enterprise 2014}

As a status of basic law, the Constitution 2013 recognizes the right to freely conduct business in the most general way. In order to implement this right in practice, only a common principled article in the Constitution (Article 33 of the Constitution 2013) is clearly not enough. Therefore, the law in general and specialized laws in particular must be responsible for creating a clear, complete legal basis for organizations and individuals to easily, conveniently and effectively implement the right to freely conduct business. In short, both Vietnam's legal system has a very important role in implementing this constitutional right. For example, in order to exercise the right to freely conduct business, citizens and legal entities firstly must have the freedom to establish businesses, which means having the right to build (formulate) business production models that they stand for appropriate. Therefore, the previous Laws on Enterprise (Law on Enterprise 1999; Law on Enterprise 2005) and the current Law on Enterprise (Law on Private Enterprise 1990, Law on Corporate 1990, Law on Enterprise 2014) were in turn issued to answer the question of how many types of businesses are allowed to establish in Vietnam and the ways as well as conditions to establish these types of businesses so that investors can choose freely (Luan Nguyen Thanh, 2015: 34-38). For example, the Law on Enterprise 2014 recognizes four types of businesses in Vietnam as private enterprises, limited liability companies, joint stock companies and partnerships.

The right to freely conduct business is not only reflected in the investor's right to choose a business model, but also in that whether they can have the right to trade in industries that they have not registered with the competent authorities or not. According to the Law on Enterprise 2005, enterprises do not have this right, because according to Article 9 of the Law, enterprises have business obligations in accordance with the business fields stated in the business registration certificate. Itmeans that, according to the Law on Enterprise 2005, there are industries that are not prohibited by law but if they have not been registered with the State by the business, the business is not allowed to trade in those fields. In summary, according to the Law on Enterprise 2015, a prerequisite condition to be able to do business in an industry is that the industry must be registered at a competent state agency. This provision is clearly no longer consistent with the spirit of business freedom of the Constitution in 2013, so it was canceled and replaced by a new regulation by Law on Enterprise 2014, whereby enterprises were proactively in selecting field and were able to do business in that field provided that if those fields are business industries with conditions, those conditions have been fully met by the enterprise (Article 8) without depending on whether the industry has been registered with the State or not (Article 29). Many aspects of the right to freely conduct business have been introduced by the Law on Enterprise 2004, as a specialized law, which is more specific, clear, progressive than the Law on Enterprise 2005 to contribute in bringing the principle of business freedom recorded in the Constitution into our life.

\section{- The role of Law on Investment 2014}

In order to execute the right to freely conduct business in practice, one of the very important issues that the legal system needs to address is the need to clearly and fully identify the banned industries and business in Vietnam. This task, obviously, is not in the "responsibility" of the Constitution and is not in the "function" of the Law on Enterprise but under the "mission" of another law, which is the Law on Investment. In implementing its duties, the Law on Investment 2014 has clearly defined that there are currently six occupations which are banned from business in Vietnam today.

Especially, the Law on Investment 2014 also confirmed a principle of immutability, whereby specialized laws are not authorized to regulate the industries, fields that are prohibited from business, as this is considered an "exclusive work" of the Law on Investment.

In Vietnam, in addition to occupations that are prohibited from business, there are industries that are not banned and are allowed to do business but enterprises must fully meet certain conditions. This industry is called conditional business. Talking about conditional business means talking about when and under what conditions that the subject has the right to be able to implement (deploy) in practice the industries that he/she is allowed to do.

Hence, freedom in business does not mean the freedom to perform the work which is allowed to do without any conditions. The regulation of business conditions does not conflict with the right 
to freely conduct business. It is an indispensable element for the subject to exercise their right to freely conduct business in practice. In fact, the number of prohibited business lines is very small while the conditional business is numerous. Currently, according to the list issued together with the Law on Investment 2014, there are 267 occupations in conditional business in Vietnam. Therefore, with the promulgation of the list of conditional business lines, the Law on Investment 2014 has made an important contribution to the implementation of the right to freely conduct business in Vietnam.

\section{- The role of Civil Code 2015}

In the Vietnamese legal system, the Civil Code plays a particularly important role in ensuring the implementation of the right to freely conduct business, which is recorded in the Constitution 2013. This role is reflected in these following key points:

Firstly, the Civil Code 2015 strengthens the economic foundation (material foundation) for production and business activities of enterprises, namely:

(i) The Civil Code 2015 finalizes the ownership regime, and also recognizes other rights for the assets of enterprise.

Like any other subjects of civil law relations, if enterprises want to operate, they must have independent assets. The property independence of the business must be expressed through certain legal forms, first of all is the ownership right and other rights on the property that countries call "other types of rights in rem (rights to things)". The Civil Code 2015 pays a great deal of attention to the recognization of ownership, while it is not "impassioned" in recognizing other types of rights in rem. This has undoubtedly undermined the independence of enterprises' assets, which has had a significant impact on the implementation of production, business activities and the enterprise's right to freely conduct business. Overcoming this situation, the Civil Code 2015 devoted a chapter of Chapter XIV to regulate other types of rights in rem aparting from ownership, which are the right to adjoining immovable property (Section 1, Chapter XIV), usufruct rights (Section 2, Chapter XIV) and surface rights (Section 3, Chapter XIV). Having these rights, independence - a leading requirement of enterprises' right to freely conduct business has been fundamentally improved (Luan Thanh Nguyen, Ngoc Thi Ha, 2018: 41-49).

(ii) The Civil Code 2015 recognizes equality between property owners.

In order to have freedom in business, one of the indispensable conditions is that businesses as property owners must be treated equally by the State. The Constitution 2013 has only recognized the equality between businesses with the status as business entities of all economic sectors. This means that enterprises in the private or state economic sector, when participating in market relations, are treated equally by the State prior to the law. This provision of the Constitution 2013 is necessary but not enough to ensure the equality of businesses in economic exchanges because there will be no real equality if in terms of assets, businesses cannot have the same protection from the State. Overcoming this situation, the Civil Code 2015 recognized the equal rights of all owners through the provisions of Clause 1, Article 3, whereby all individuals and legal entities are "protected equally about moral rights and property".

(iii) The Civil Code 2015 recognizes the unlimited number and value of assets owned by organizations and individuals.

There will be no freedom in business if business entities, including enterprise, are restricted by law in terms of the quantity and value of the property they wish to acquire in the property owned by themselves. In summary, there is freedom to decide the size of transactions in the marketplace in the freedom of business. If this is restricted by law, it is considered that there is no freedom in business. Therefore, the Civil Code 2015 continues to provide regulations whereby individuals and organizations have the right to own property with no restrictions on quantity and value, is considered as an important legal guarantee for implementing freedom in business in Vietnam (paragraph 2, Article 205).

Secondly, the Civil Code 2015 strengthens the legal basis for implementing the freedom of contract.

Freedom of contract is one of the basic components in the content of freedom in business everywhere, including Vietnam. Therefore, it can be affirmed that without contractual freedom, 
there is basically no freedom in business. Being aware of this relationship, Vietnamese legislators have paid special attention to the process of building the third part of the Civil Code (Obligations and contracts). These following are the new regulations that are of great significance in ensuring the implementation of contractual freedom in Vietnam.

Firstly, the Civil Code 2015 recognizes the principle that, under which contract with whom and with what content (freedom of agreement) is the right of the business; no one, including a state agency, may intervene, except for special cases prescribed by law (paragraph 2, Article 2; clause 2, Article 3).

Secondly, the Civil Code 2015 recognizes the full, clear and unified conditions for unilateral termination of the contract, especially the addition of conditions: "the other party seriously violated contractual obligations". Currently, according to the Civil Code 2015, unilateral termination of contracts can be done relatively easy. Obviously, there will be no freedom in business if legally established contractual relations can be arbitrarily canceled by an unilateral party, the Vietnamese legislator has set out rules to limit to the lowest level of this situation. In particular, paragraph 1, Article 423 has provided regulation, whereby one party may unilaterally terminate the contract if the other party seriously violates the contractual obligations. In this law, it also defines what is a serious violation of contractual obligations to avoid understanding and applying it arbitrarily and subjectively in practice.

Thirdly, the Civil Code 2015 sets out the principle of priority to apply specialized laws, thereby demonstrating the State's more respectful attitude towards the freedom of agreement among parties in contracting and implementing contracts in some specific business areas.

The Civil Code 2015 has many regulations that promote the freedom of agreement of the parties in the contract. However, there is no specific and adequate regulation on the relationship between the Civil Code and the specialized laws such as the Law on Credit Institutions, the Law on Insurance Business, the Law on Real Estate Business,...Hence, when entering into contracts in these areas, the subject's freedom of agreement is no longer guaranteed at the necessary level according to the requirements of practice (Tuyen Nguyen Quang, Luan Nguyen Thanh, 2016: 8693). For example, Paragraph 1, Article 476 of the Civil Code 2015 states, "the rate of interest for a loan shall be as agreed by the parties but may not exceed one hundred and fifty (150) per cent of the basic interest rate announced by the State Bank for the corresponding types of loans". This regulation has led to two very different interpretations, related to the freedom of agreement on lending interest rates in the banking sector. The first perspective (mainly Judges) said that the lending interest rate in all credit contracts is under the control of the Civil Code, which means that the parties have the right to freely agree but must not exceed $150 \%$ of the basic interest rate announced by the State Bank corresponds to each kind of loan. The second perspective (mainly from the State Bank and commercial banks) said that the provisions on this ceiling of lending interest rate are only applicable to the signing of ordinary civil contracts but do not apply to Bank credit contracts. Also from this point of view, banking business is a specific business, so to ensure the freedom of business of commercial banks, the parties have the right to agree on the lending interest rate without being limited by the interest rate set by the Civil Code in 2005. In fact, many bank credit contracts have been declared invalid to by the lending interest rate by the court as it has exceeded the ceiling interest rates regulated by the Civil Code. Overcoming this situation, on the basis of taking into account the characteristics of some business sectors in general and banking business in particular, Vietnam's legislators for the first time clearly recognized the relationship between the Civil Code 2015 (as a general law) with specific laws (as a specialized law), accordingly, when there is a difference between the Civil Code and the specialized law on some points, the priority is to apply specialized law (clause 1, Article 4). This thought has also been confirmed once more time in Article 468 of the Civil Code 2015, whereby: "Interest rates are agreed by the parties. In case the parties have an agreement on interest rates, the agreed interest rate must not exceed 20 \% year of the loan, unless otherwise prescribed by law".

Therefore, by allowing the parties more freedom in solving problems arising in specialized business areas, the Civil Code 2015 has greatly contributed to creating more mechanisms in implementing the right to freely conduct business of enterprises in Vietnam in the up-coming time.

Fourthly, the Civil Code 2015 had new regulations to limit the cases of invalidated contracts due to violations of the form. The Civil Code 2005 sets out many cases where the contract is invalidated, in which there is a case of invalidation due to violation of the form. For example, a 
legal contract must be notarized but if this request has not been followed, a party may ask the court to invalidate it, even if in fact, this contract has already been done by the parties. This provision is clearly rigid which does not guarantee the stability of market relations, causing many difficulties in practice, especially encouraging the protection of those people who lack goodwill and dishonesty in civil exchange. Overcoming this situation, the Civil Code 2015 has introduced many regulations, whereby, in certain cases, under certain conditions, despite the fact that the contract is breach of form but it may still be declared not invalid by a court (Article 129).

Fifthly, the Civil Code 2015 has many regulations that make it easier and more convenient for owners of civil law relations in general and businesses in particular when entering into and performing contracts. For example, under the provisions of Clause 2, Article 137, a legal person may have more than one legal representative. Therefore, this provision has ended the situation that a legal entity can only have one legal representative, overcame many difficulties for large enterprises which have a multi-sectoral, multi-business scale and operate in many different territories in signing contracts. According to the Civil Code 2005, an authorized person is understood to be an individual and cannot be a legal entity. This provision has restricted the right of enterprises to authorize other legal entities in performing jobs that they cannot directly perform, which reduces the possibility of contracting in dynamic business conditions of businesses nowadays. In order to get over this situation, the Civil Code 2015 has added a very new important regulation which can be able to make it easier for enterprises in entering into contracts, that is the provision specified in Clause 1, Article 138, by which the legal person may be an authorized representative.

\section{Thirdly, the Civil Code 2015 strengthens the mechanism of civil rights protection.}

One of the new points with landmark in the Constitution 2013 is the promotion of human rights and civil rights. The Constitution recognizes fundamental rights and identifies the key mechanisms to ensure the exercise of these rights, while other laws, including the Civil Code, must find and recognize specific mechanism to contribute to protect basic rights of citizens and legal entities, including enterprises. Here are some new regulations with a view to creating a better legal basis for the protection of civil rights of the organizations and individuals, including businesses:

Firstly, State agencies, including the Court, are not allowed to refuse resolving civil cases on the grounds that there is no law to apply.

There is an intimate relationship between the right to freely conduct business and the mechanism of protection of freedom in business. If the law allows businesses to have freedom in business but does not provide adequate mechanisms and solutions to ensure that the rights of business arising from economic activities are always in the protection of the State, businesses will not feel safe in executing their investment, production and business activities with their wish, and consequently, the right to freely conduct business will not be implemented thoroughly in reality. For example, currently, according to the Law on Enterprises 2014, enterprises have the right to freely decide on business lines, even if the lines are not regulated by the State in the system of Vietnamese economic industries. Such regulations are intended to encourage businesses to always explore, create, and do business in whatever thing they may think of without limiting their business in existing industries. However, this provision of the Law on Enterprise 2014 will certainly not be enthusiastically responded by businesses, because businesses cannot avoid the psychology of concern that, when doing business in these industries and disputation arises, whether the State will accepts to resolve them and protect businesses' legitimate rights or not? In order to meet this requirement, the Civil Code 2015 issued a regulation whereby the competent state agencies, including the Court, are not allowed to refuse to resolve civil cases with reasons for not having the law to apply (clause 2, Article 4). Hence, the Civil Code 2015 has contributed to encourage businesses to expand production and business, which has contributed to ensuring the implementation of the right to freely conduct business through the commitment of the State that, in any cases, even if there is no law to regulate, if the business has conducted production and business activities legally and benefitted themselves and society, then their rights and advantage will also be protected by the State by all means.

Secondly, the Civil Code 2015 recognized a new mechanism in protecting civil rights, whereby, in many cases, administrative decisions can be reviewed under judicial procedures in court. 
Currently, in Vietnam, many civil issues are being handed over to the state agencies to resolve. This is inevitable due to the characteristics of the organizational structure and management mechanism of our State. However, this mechanism in addition to the positive side also contains many limitations. If this mechanism continues to exist without innovation, it will certainly hinder production and business activities of enterprises, because the mechanism of resolving disputation by administrative route does not guarantee the demand for the process of resolving civil disputes such as a rule of openness, transparency, independence of the dispute resolution process. Only the Court, with specific provisions in judicial proceedings, can better protect the legitimate rights of the business. Therefore, the Civil Code 2015 makes regulations, by which administrative decisions can be reviewed at judicial agencies is considered as a new regulation, which contributes to better protection of legal rights of enterprises, thereby creating conditions for enterprises to exercise their freedom in business (Clause 1, Article 14).

Thirdly, the Civil Code 2015 protects fairness, fights for injustice in civil transactions, thereby contributing to promote the implementation of freedom in business of enterprises. According to the Civil Code 2015, the parties are obliged to comply with the rights and obligations arising from the contract. This is a reasonable and necessary regulation to ensure order in economic exchanges, and simultaneously protect legitimate rights and interests of related parties thoroughly. However, recent reality has shown that if in all cases the law requires the parties to strictly abide by the rights and obligations arising from the contract, it will create an injustice in the mutual benefit between parties. For example, in the process of contract performance, if new circumstances appear that the parties may not anticipate when sign the contract and if the contract continues to be implemented, one party will be seriously damaged. Stemming from the principle of goodwill, cooperation in contracting and implementing contracts (clause 3, Article 3), in order to ensure the harmonization of interests between the parties, overcome the situation in which one party is damaged, while the other party has benefited in an unjustified way, the Civil Code 2015 has introduced a new provision in Article 420, whereby, in the above case, the affected party has the right to request the other party to change or cancel the contract. When the request is rejected, it is able to ask the Court to base on the specific circumstances of the case to declare the cancellation or amendment of the contract. This provision is completely reasonable, consistent with the production and business in practice of enterprises in the market economy with many changes that are not foreseen and it is also consistent with the laws and commercial custom of many countries around the world. Another example, in the former Federal Republic of Russia, during the 70-year existence of a centrally planned economy, there was such none of this provision in the Civil Code. However, after building a new economy, a social-oriented market economy, the Civil Code 1993 supplemented the provisions of Article 451: "Amending and canceling contracts due to changing circumstances in basic way. By studying the content of this article, this rule basically has the same contents as Article 420 of Vietnam's 2015 Civil Code.

\section{Research result}

In the context of globalization and opening market, the right to freely conduct business is increasingly focused and ensured by the Vietnamese legal system, from a constitutional right recognized in the Constitution to those specific provisions in specialized laws, especially the Civil Code 2015, the Law on Enterprise 2014, the 2014 Investment Law. First of all, freedom in business as a constitutional right guarantees basic rights of human and civil rights, allows natural persons and legal entities to participate in economic exchanges proactively with occupations that are not prohibited by law, promotes the spirit of ownership and rightly enrichment, creates a driving force for economic development and social stability. The Law on Enterprises and the Law on Investment play an important role in establishing a legal basis for different types of businesses that natural persons and citizens can establish and trade in industries that are not prohibited by law, regulating conditional business sectors and creating a clear mechanism to allow businesses to expand business lines. In particular, the progressive regulations in the Civil Code 2015 have ensured maximum freedom of business. Freedom in business as a civil rights is appropriately and progressively regulated in the Civil Code 2015, which have not only motivated businesses to participate more deeply in civil exchanges but also establishing a mechanism to protect this civil rights to be carried out fairly and strictly, in accordance with the continuous development of civil exchanges in particular and the economy in general. 


\section{Conclusion}

Currently, Vietnam has only about half a million enterprises, it means that on an average of nearly 200 people, there is a business, while in developed countries, from about 15 to 20 people, there is a business (Nhat Nam, 2016). With the strategy of "Start-up country" which has been constantly innovating in recent years, our State has had policies to support and promote start-up businesses, especially to mention the efforts to improve the system of legal basic, especially regulations on ensuring freedom in business. Freedom in business must be considered as a prerequisite for enterprises to actively choose appropriate forms of organization and freely conduct business in industries that are not prohibited by law, which is the key to get successful "start-up country" and sustainable development. Ensuring the right to freely conduct business by legal mechanism taking into account the arising factors, changes in the new situation are the requirements and challenges posed to the Vietnamese legal system. At a certain level, somehow, it can be said that the current Vietnamese law provisions basically ensure and create conditions for citizens' right to freely conduct business to be maximized and implemented effectively.

\section{References}

Law on Enterprise, 2014 - Law No. 68/2014/QH13 of November 26, 2014 of National Asembly of Vietnam posted on the website of Vietnam Law in English. [Electronic resource]. URL: http://vietnamlawenglish.blogspot.com/2015/05/vietnam-enterprise-law-2014.html

Law on Investment, 2014 - Law No. 87/2014/QH13 of National Assembly of Vietnam on investment of November 26, 2014 posted on the website of Legal normative documents. [Electric resource]. URL: http://vietnamlawenglish.blogspot.com/2015/o5/vietnam-enterprise-law2014.html

Luan Nguyen Thanh, 2015 - Luan Nguyen Thanh (2015). New points, facilitating businesses of the Law on Enterprise 2014. Vietnamese Lawyer Journal, No. 7/2015, pp. 34-38.

Luan Thanh Nguyen, Ngoc Thi Ha, 2018 - Luan Thanh Nguyen, Ngoc Thi Ha (2018). The legal The Legal Nature of Land Use Rights in Vietnam. Russian Journal of Comparative Law, Vol (5), Is. 2, pp. 41-49.

Nhat Nam, 2016 - Nhat Nam (2016). Start-up country - What opportunities for Vietnam?[Electric resource]. URL: http://baochinhphu.vn/Tin-noi-bat/Quoc-gia-khoi-nghiepvanhoi-nao-cho-Viet-Nam/281377.vgp

Tuyen Nguyen Quang, Luan Nguyen Thanh, 2016 - Tuyen Nguyen Quang, Luan Nguyen Thanh (2016). Amendments and supplements of the Law on Real estate business 2014 on real estate service business. Jounal of Law. No. 10/2016, pp. 86-93.

Vietnamese Civil Code, 2005 - Vietnamese Civil Code No. 33/2005/QH11 of June 14, 2005 posted on the website of World intellectual property organization. [Electronic resource]. URL: https://wipolex.wipo.int/en/legislation/details/4125

Vietnamese Civil Code, 2015 - Vietnamese Civil Code No. 91/2015/QH13 of November 24, 2015 posted on the website ofWorld intellectual property organization. [Electric resource]. URL: https://wipolex.wipo.int/en/legislation/details/17200

Vietnamese Constitution LawAct, 2013 - Vietnamese Constitution Law Act, 2013 posted on the website of the Ministry of Justice. [Electronic resource]. URL: http://moj.gov.vn/vbpq/lists/vn\%2obn \%2ophp\%2olut/view_detail.aspx?itemid=28814 